\title{
Communicating Knowledge and Identities Audiovisually in Exhibitions: Participatory Approaches at the Slovene Ethnographic Museum
}

\section{Nadja Valentinčič Furlan}

\section{(2) OpenEdition \\ Journals}

Electronic version

URL: http://journals.openedition.org/anthrovision/3114

DOI: 10.4000/anthrovision.3114

ISSN: 2198-6754

Publisher

VANEASA - Visual Anthropology Network of European Association of Social Anthropologists

\section{Electronic reference}

Nadja Valentinčič Furlan, « Communicating Knowledge and Identities Audiovisually in Exhibitions: Participatory Approaches at the Slovene Ethnographic Museum », Anthrovision [Online], 6.1 | 2018 Online since 31 December 2018, connection on 28 July 2019. URL : http://journals.openedition.org/ anthrovision/3114; DOI : 10.4000/anthrovision.3114

This text was automatically generated on 28 July 2019.

(c) Anthrovision 


\title{
Communicating Knowledge and Identities Audiovisually in Exhibitions: Participatory Approaches at the Slovene Ethnographic Museum
}

\author{
Nadja Valentinčič Furlan
}

\section{Introduction}

1 In the $21^{\text {st }}$ century, the construction of knowledge in ethnographic museums, as well as in visual anthropology, has been subject to repeated and substantive change. In museums, it has become increasingly common to see visitor participation and collaboration, the inclusion of vulnerable social groups, multivocality and shared authority in shaping exhibitions and programmes. This affects the construction of knowledge and identities in fundamental ways.

2 In this article, I focus on how the permanent exhibition I, We, and Others: Images of My World at the Slovene Ethnographic Museum is presently shaped by paradigms resulting from epistemological developments going back at least a century. In a case study of the permanent exhibition and its supporting programmes, I concentrate on the use of film and participatory approaches. Analysing knowledge construction, I argue that films and exhibitions co-curated by visitors, revealing their subjective point of view, facilitate 'contact zones' (after Clifford 1997) of various individuals and groups of people in the museum. 


\section{On Knowledge Construction in Ethnographic Museums and Films}

In the $19^{\text {th }}$ and the greater part of the $20^{\text {th }}$ centuries, curators collected objects, attributed significance to them and monopolised the definition of heritage. "As custodians of institutional collections they added legal ownership to intellectual ownership" (Mensch and Meijer-van Mensch 2015: 59). In the late $20^{\text {th }}$ century, museums had to redefine their social role, abandon their authoritative elitist stance and move closer to visitors' needs, also in the field of knowledge construction.

Similarly, the beginnings of ethnographic films were primarily distant observations of the filmmakers that were believed to be 'objective' views, thus part of positivist paradigm. Some authors of the articles in Principles of Visual Anthropology (ed. Hockings 1975) which laid the foundations of academic discipline, distanced from the alleged objectivity. The 'participant camera' or 'shared cine-anthropology' by Jean Rouch, and 'participatory cinema' by David MacDougall were presented as encounters between the researcher and the researched.

In 1986, basic anthropological concepts, such as culture, object and subject, authority, methodologies and practices of representation were thoroughly rethought in the book Writing Culture: The Poetics and Politics of Ethnography. Edited by James Clifford and George E. Marcus, the book triggered a ground-breaking, reflexive and postmodern turn in anthropology. In particular among visual anthropologists, questions of voice, authority, authorship and knowledge construction have become serious concerns. In 1991, Jay Ruby wrote, "who can represent someone else, with what intention, in what 'language', and in what environment is a conundrum that characterizes the postmodern era" (Ruby 2000 [1991]: 196). ${ }^{1}$ The answers have been multiple, including participatory and collaborative film productions with 'sharing authorship' (Ruby 2000 [1991]: 208), multivocal strategies and reflexivity (MacDougall 1992: 31). These can create circumstances for the generation of new knowledge between film subjects and filmmakers instead of simply confirming the a-priori knowledge of the filmmaker (MacDougall 1992: 39).

6 In 1991, Ivan Karp and Steven D. Lavine edited the volume Exhibiting Cultures: The Poetics and Politics of Museum Display, the subtitle probably refers to Writing Culture. Here, too, James Clifford was among the authors, and later he wrote the much quoted article Museums as Contact Zones (1997). The concept was borrowed from Mary Louise Pratt, who defined a 'contact zone' as "the space of colonial encounters, the space in which people geographically and historically separated come into contact with each other and establish ongoing relations, usually involving conditions of coercion, radical inequality, and intractable conflict" (1992: 6). Clifford stated "when museums are seen as contact zones, their organizing structure as a collection becomes an ongoing historical, political, moral relationship - a power-charged set of exchanges, of push and pull" (1997: 192-193). Curators rethought museums and their roles, acknowledging inequalities of power and emphasizing the necessary ethics.

7 Museologist Eilean Hooper-Greenhill's concept of 'post-museum' eliminates the difference between high, popular and folk culture. With the recognition that each truth is only partial, depending on the interpreter, the curator's interpretation has ceased to be privileged. The museum has lost its authority over the production of knowledge; the 
voices of those previously silent or 'spoken for' and the points of view of neglected social groups have started to be included in fundamental ways. The cacophony of voices now presents a range of views, experiences and values. Taken for granted facts are deconstructed and seen from new perspectives (Hooper-Greenhill 2000: 148-153). The central change in exhibition policy is based on the recognition that museum objects are not ends in themselves, but rather means to understand people's social worlds. The focus of museum exhibitions has shifted from objects to people, their knowledge and their identities. This process was paralleled by the UNESCO Convention for the Safeguarding of the Intangible Cultural Heritage (2003) that included formerly overlooked communities, practices and traditions, and gave recognition to social knowledge, skills and processes. In both visual anthropology and museology, the audience had, until the last quarter of the $20^{\text {th }}$ century, been patronisingly ascribed passive receiving of films or exhibitions. In relation to film production and viewing, MacDougall (1978: 422) sketched a triangle of meaning constructed among film subject, filmmaker and film viewer. In a similar way, Michael Baxandall defined three agents in discerning the meaning in museum exhibitions: the creator of the object, the exhibitor = the author of the interpretation, and the viewer (1991: 2-3). In the words of Hooper-Greenhill, "the politics of address and the concept of the voice have become significant. Who is being addressed, how they are spoken to, and who is speaking and how, have become major targets for analysis. These matter raise questions of identity and subjectivity. Subjectivity needs to be understood as something in process [...]. [It] is always gendered, and based in class, race, ethnicity and sexual orientation" (2000: 142).

In heritage studies, Laurajane Smith (2006) defines the dominant heritage discourse, including the academic one, as "authorized heritage discourse", while on the other side she situates the "subaltern heritage discourse" of the heritage bearers. She writes that "social meanings, forms of knowledge and expertise, power relations and ideologies are embedded and reproduced via language. The discourses through which we frame concepts, issues or debates [...] constitute, construct, mediate and regulate understanding and debate" (Smith 2006: 4), and they also influence our behaviour. Her division refers to the power of the groups mentioned, and being aware of it, institutions can give more space and power to the heritage bearers and users. If museums want to facilitate inclusive environments for life-long learning, visitors are to become agents, collaborators and cocreators of exhibitions and programmes.

In visual anthropology, the emancipation of former film subjects and film viewers led to indigenous and subject generated cinema; and the communities were often supported by visual anthropologists. ${ }^{2}$ Faye Ginsburg claims that indigenous media offer possible social, cultural and political means for reproducing and transforming cultural identity of indigenous people, thus availing the understanding of the multiple ways cultural realities are experienced. The indigenous and ethnographic films produce the 'parallax effect' with two perspectives that give impression of three-dimensionality. Due to changed understanding of culture and representation, the shifting toward more dialogical, reflexive, and imaginative modes of representation have developed (Ginsburg 1995: 73-74).

11 As a case study I will present the knowledge construction in the permanent exhibition I, We, and Others: Images of My World of the Slovene Ethnographic Museum, with focus on the audiovisual communication and participatory strategies. Visitors have been activated in creating personal exhibitions and cooperating in reciprocal audiovisual project. I will 
address concepts of reflexivity, the inclusion of vulnerable social groups, multivocality or multiple perspectives of the world, shared authority and a Pro-Am (ProfessionalAmateur) approach in shaping exhibitions and programmes.

Figure 1: The Slovene Ethnographic Museum.

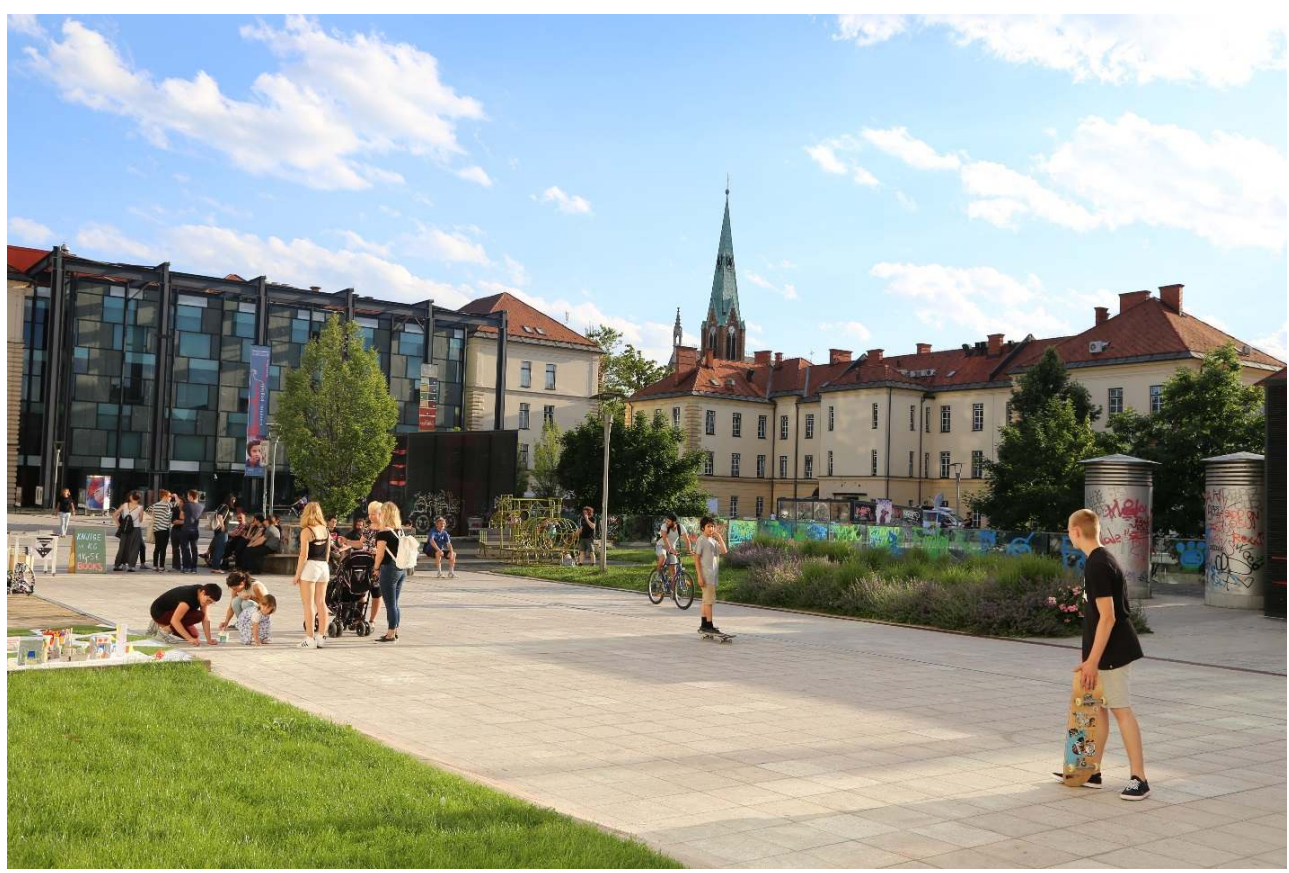

The exhibition building on the left and the administrative building on the right, Ljubljana, 2017.

Photo by Jure Rus.

\section{The Slovene Ethnographic Museum and the Exhibition I, We, and Others: Images of My World}

12 The curators of the Slovene Ethnographic Museum have set up two permanent exhibitions with complementary concepts (scenarios), both combining contents and objects of Slovene and non-European origin. ${ }^{3}$ The exhibition Between Nature and Culture (2006) is collection-based, but nevertheless the material cultural heritage is contextualised with a considerable number of filmic interventions, depicting how, where and by whom the objects were used or produced. Its counterpoint, I, We, and Others: Images of My World (2009) is oriented towards people and their identities. They correspond to two predominant models of exhibitions, "a vehicle for the display of objects" and "a space for telling a story" (Karp 1991: 12). While I return to the first exhibition later in this article, I am first and foremost here concerned with I, We, and Others: Images of My World. This reflexive exhibition presents cultures, heritages and identities as processes, drawing attention to the relativity of the concepts of Us and Others (Žagar 2019: 10).

The challenge was how to display this rather abstract content so that it would be relevant to a museum visitor from any part of the world. Identities and positioning in the world are introduced as a mosaic of possibilities, a network from slovene and other cultures, together with some corresponding cases from animal communities. At the same time, visitors are encouraged to reflect on their own identities by questions in the first person 
singular, such as: Who am I? Who are my family? Where am I from? Which people do I feel as my people? What drives me to foreign lands among other people? Where do I come from and where am I going? These questions function well for everybody, initiating inner dialogue, so visitors find their individual answers which are subjective and relative.

Texts, pictures, objects and films present identities related to an individual, home and family, community, profession, nationality, language and country, and they also disclose people's mental landscapes, such as their world views, knowledge, wisdom and values.

How is this whole story told? The curators conceived the exhibition narrative as a universal overall storyline with a number of variations in texts, objects, photographs and films, while subjective passages are brought in through excerpts from a historical novel, home video, filmed life stories, fairy tales and life experience. Besides seven fixed parts, there are also two rooms for personal exhibitions of the visitors in the so called museum living room. Here, visitors provide their individual and highly subjective answers about their identities, memories and personal heritage, which can be a 'bricolage' of bits and pieces (Lévi-Strauss 1962 in Žagar 2019), or in the form of their private collections, or the result of their own creativity. The authors are supported by curators who pose questions on content, methods, media and programmes.

\section{Developing Audiovisual Communication for the Exhibition}

Filmic approaches in the exhibition I, We and Others: Images of My World are eclectic - the genres vary from home video, edited footage on intangible cultural heritage and archival documentaries to purposely filmed narrations and a video portrait. ${ }^{4}$

Figure 2: Ground plan of the exhibition I, We, and Others: Images of My World with media points.

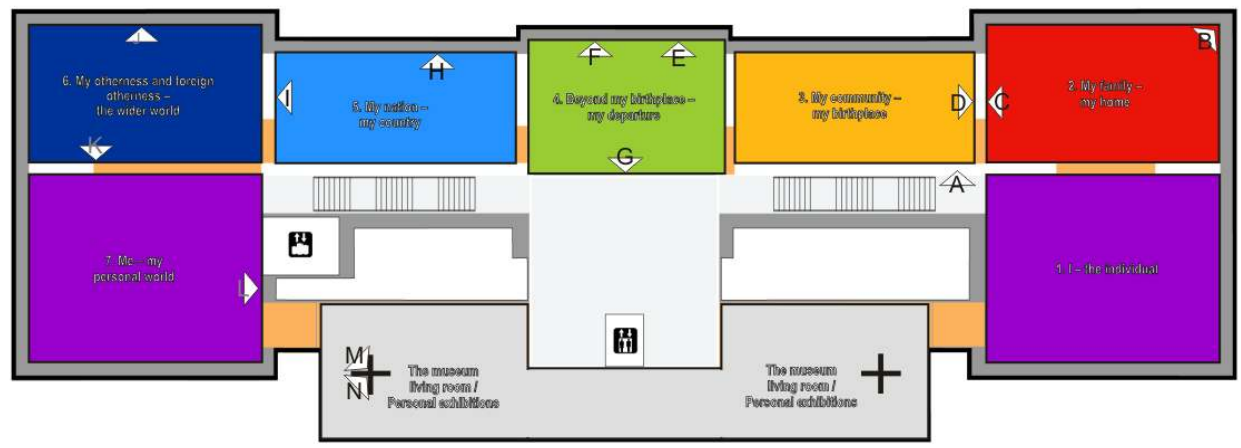

Media points: A Faces. B Fire in the hearth. C Raubarjevi (interactive). D Setting up a Maypole; Otepovci. E Pilgrimage. F Urban from Ribnica (pedlar). G Washerwomen from Bizovik. H National anthems. I Popularised songs. J In German Sudan (excerpts). K The Alexandrinian Women and Their Descendants (interactive). L My World through Fairy Tales and Experience (interactive). M Vesna (interactive). N Gallery of Narrations and Portraits (interactive)

Prepared by Jure Rus, Joža Jamšek and Nadja Valentinčič Furlan.

17 In the section My family - my home, we present recordings by Hanzi Reichmann from Želuče in southern Carinthia, Austria. At the interactive media point Raubarjevi (the family folk name), several short video clips of everyday and festive family life are available. This content is subjective and intimate: the father, enthusiastic about filming, was the insider with the best access to family moments. Having produced hours and 
hours of recordings over two decades, he had the full trust of family members. When invited to cooperate and given some suggestions on the content, he deliberated on what to show to the public, sending two hours of material. We then organised it in an interactive media point and added some contextual data on the filmmaker, the family and their homestead. The Reichmann family were very proud when they saw the media point. Using private footage in the exhibition, we pay tribute to home video and prompt reflection on what people find worthy of documenting in their family life.

Figure 3: Media point in the section on home and family.

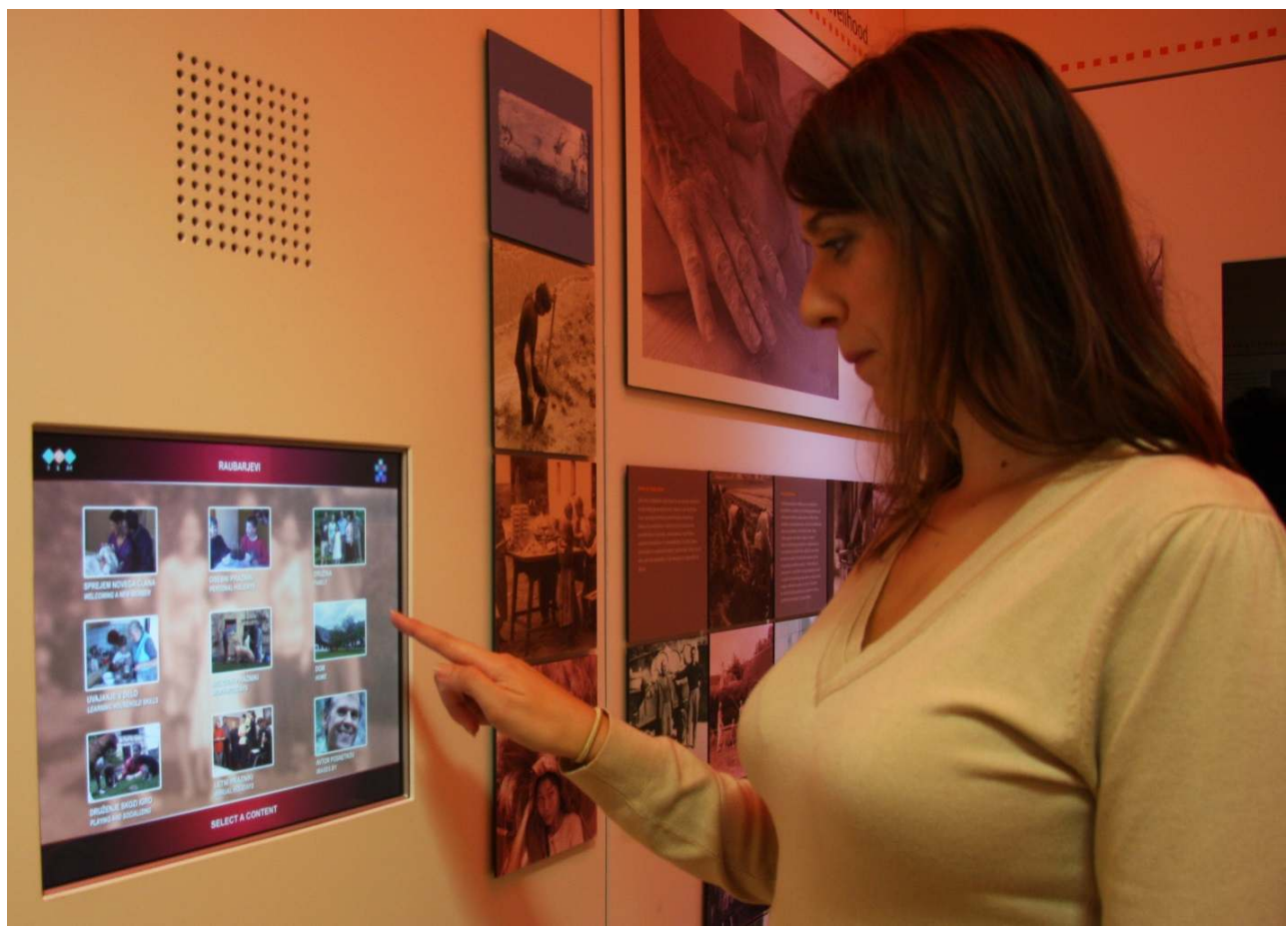

A visitor selects home videos at the media point, SEM, 2010.

Photo by Miha Špiček.

18 In the section My community - my birthplace we use edited ethnographic footage of a traditional custom of setting up a maypole in the village of Drašiči in White Carniola. It is carried out by the village community with the assistance of the local fire brigade. Setting up a Maypole brings a very condensed audiovisual narrative on how male villagers raise the maypole manually, which requires well-coordinated action. The encouraging calls of the leading person and the synchronous movements of all the men are characteristic sounds and images of a united community. ${ }^{5}$ Knowing the villagers very well, curator Andrej Dular filmed the event using the observational method. 
Figure 4: Media point in the section on community.

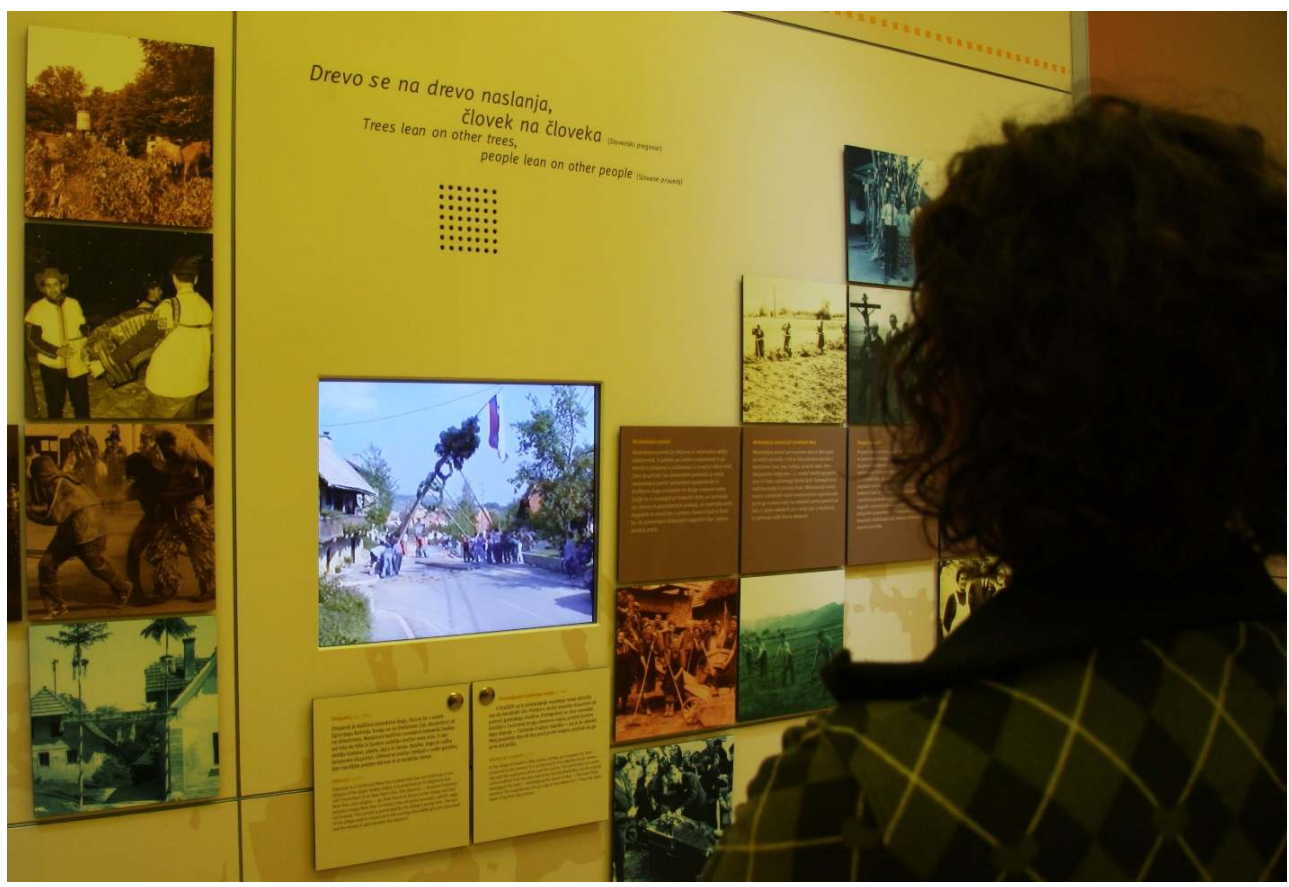

A visitor watches the raising of the maypole, SEM, 2009.

Photo by Miha Špiček.

This media file cannot be displayed. Please refer to the online document http:// journals.openedition.org/anthrovision/3114

Video link: https://www.youtube.com/watch?v=1FX3YzEH8P0

The section My otherness and foreign otherness - the wider world builds on different motives for travelling to foreign countries, embodied in missionaries, researchers, political representatives, inventors, economic immigrants, tourists, etc. Excerpts from the documentary In German Sudan (1917) bear witness to inventor Baron Anton Codelli from Ljubljana working in Africa. In 1911, he was engaged by the German company Telefunken to construct a radiotelegraph station in Kamina (in today's northern Togo), so that the Germans could communicate with their African colonies. At that time, Codelli also financed the filming of the first feature film in Africa, the White Goddess of the Wangora, by Hans Schomburgk. The same film crew documented everyday life of native peoples of the area. The feature film went missing at the outbreak of World War I (more in Frelih 2007), while documentary recordings were preserved in the silent documentary film In German Sudan. We display selected observational excerpts on everyday life in that area, such as weaving on looms, making straw hats, preparing porridge and forging. The last excerpt presents ornamented warriors shooting with bows and arrows; ${ }^{6}$ we can assume this sequence was staged and film director appears in the picture, which demonstrates a patronising attitude. 
Figure 5: Media point in the section on the world.

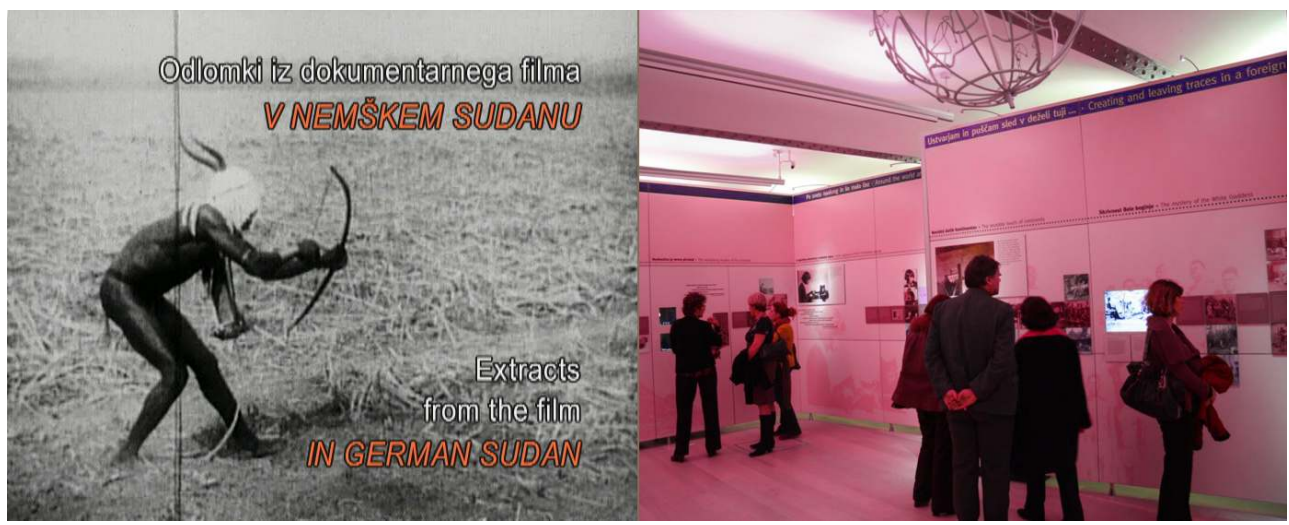

Left: A still from the film presents a warrior with a bow and a typical head ornament (1913). Right: Film excerpts are incorporated in the display of Codelli's technical adventure in Africa, SEM, 2009.

Still from Schomburgk's film; photo by Miha Špiček.

The last section Me - my personal world is devoted to mental landscapes, and knowledge construction is addressed in filmed narrations of two kinds. Fairy tales are presented as a traditional manner of transmitting universal knowledge, values, feelings and identities to coming generations. Life experience, on the contrary, is personalised wisdom generated in the course of an individual life, deeply connected to one's identities. We decided to select three narrators from each subgenre: a folk storyteller, a folklore researcher and a professional interpreter of fairy tales for the first subgenre; a Slovene person living in Slovenia, a member of the Slovene minority in Austrian Carinthia, and a non-Slovene person - a Dine Indian - for the second subgenre.

Among the filmed fairy tales, we have chosen examples of folk explanation as to how the world was created, how a certain area of slovenia received its name, and a fairy tale supporting child raising by communicating that the hard working girl will be awarded, while the lazy and disobedient one will be punished.

Fairy tales were easy to document as they are rather fixed forms, however, filming individual life experiences of narrators recommended by communities was a more complex task. I soon realised that I would only be able to elicit narrator's life experiences after filming their whole life story. Thus, the integral interviews were a 'journey' through their life cycle, from their birth, home and family, school and profession, marriage, children and grandchildren to their views of life, and only then did I ask what was most valuable to them in their lives that they wanted to pass to their offspring. Only the cream of the crop is presented in the media point My World through Fairy Tales and Life Experience. The narrators are filmed in close up, so that the viewers can establish a feeling of intimacy when viewing their contributions. 
Figure 6: Media point in the section the personal world.

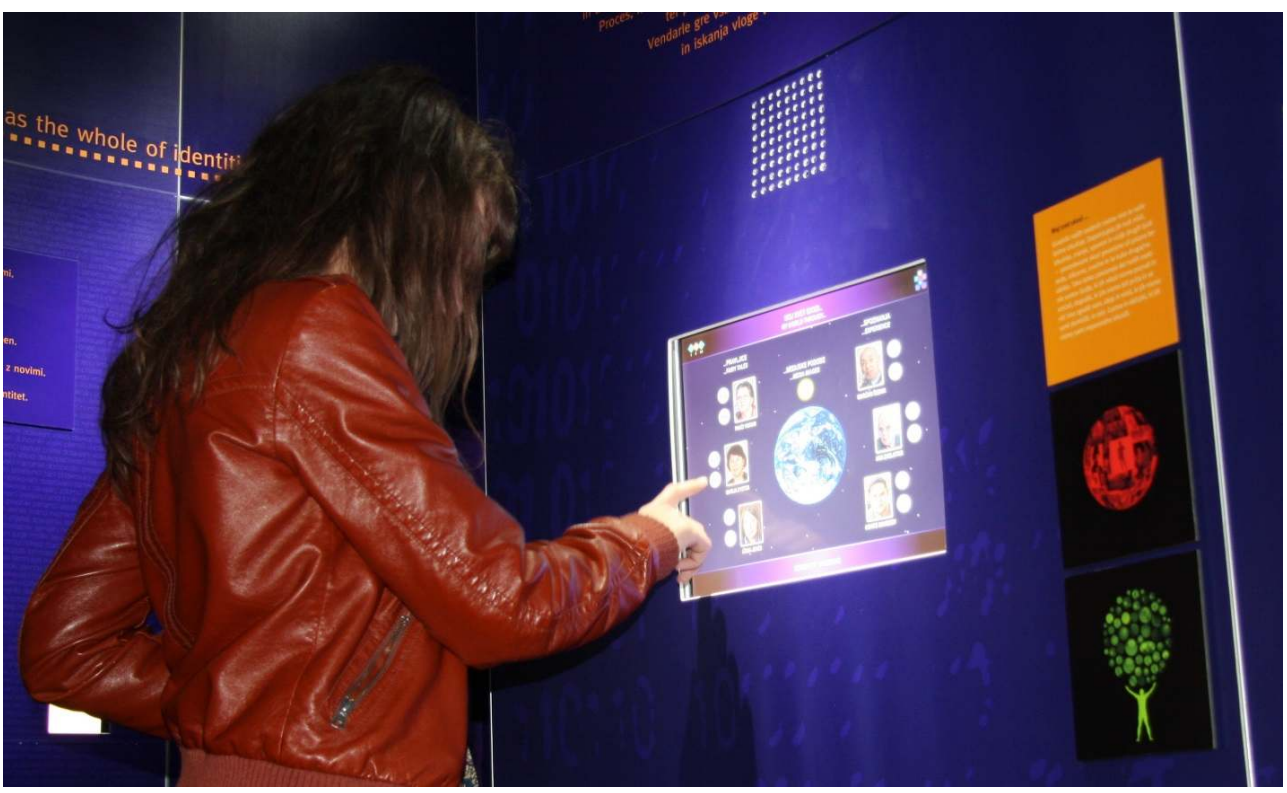

Fairy tales and life experience on an interactive media point My World through Fairy Tales and Life Experience, SEM, 2009.

Photo by Miha Špiček.

This media file cannot be displayed. Please refer to the online document http:// journals.openedition.org/anthrovision/3114

Video link: https://www.youtube.com/watch?v=-a5qxISp9xU

This media file cannot be displayed. Please refer to the online document http:// journals.openedition.org/anthrovision/3114

Video link: https://www.youtube.com/watch?v=Qn4YLNBc-XI\&t=37s

I thoroughly agree with Graham Black that the use of oral histories and filmed testimonies "presents the opportunity of multiple perspectives and can provide plural, alternative and perhaps even contradictory versions of the past and the present" (2012: 215). Another strong point of oral histories is that they are clearly subjective, therefore the viewers watching the filmed testimonies are conscious that these are stories of these very narrators. The filmed narrations do not 'colonize' the past with any constructed images created today to represent the past. ${ }^{7}$

\section{Mosaic Portrait - A Red Thread Through the Exhibition}

Being aware that filmic approaches in the exhibition are eclectic and partial, I was thinking how to make an audiovisual red thread of the exhibition on a subjective and personal level. Excerpts from the historical novel The Krka Flows On insert male descriptions of how a local miller family has undergone many historical, social and 
political changes of the $19^{\text {th }}$ and $20^{\text {th }}$ centuries. ${ }^{8}$ To balance it, I decided to make a video portrait of a young Slovene person, so that younger generations could identify (or not) with memories and views of the late $20^{\text {th }}$ and $21^{\text {st }}$ century. The aim was also to examine how rather abstract exhibition themes can be recognised and documented in real life situations and how reflexive questions function when posed to a person before the exhibition was opened. ${ }^{9}$

Vesna Maver, 25, from the village of Grant in the Tolmin region of Slovenia, was ready to cooperate in filming. The content of the portrait was generally based on the concept of the exhibition, adapted to life circumstances of the film subject. Vesna was filmed in everyday and festive situations, in her family circle, her village environment, and in the urban setting of Ljubljana, where she lived as a student. We obtained recordings from a visit by people from Rut and Grant to Innichen / San Candido in South Tyrol, today part of Italy. For 800 years, the memory has been preserved that the community ancestors migrated from South Tyrol in the early $13^{\text {th }}$ century. Contacts between the two communities were regularly kept until the late $19^{\text {th }}$ century, then abandoned in the $20^{\text {th }}$ century due to the world wars and restrictions of movements by the Italian governance, ${ }^{10}$ and were successfully re-established three decades ago.

Vesna was asked about herself and her relationships with her home, family, village community, country, nation, language, and faith. She recounted her experience of a trip to Egypt, discussed her values, and revealed how she imagined her future. While filming the portrait, the wishes of Vesna and her parents on what should remain private were taken into consideration.

The portrait of Vesna is organised in accordance with the mosaic structure of the exhibition on a touch screen. ${ }^{11}$ It functions also as a 'can opener' - an invitation to visitors to film portraits and narrations triggered by the exhibition and send their reflections to the museum. This media point is placed in the museum living room of the exhibition that is available for visitors to participate in filming or preparing their own exhibitions and programmes. 
Figure 7: Media point with the mosaic portrait.

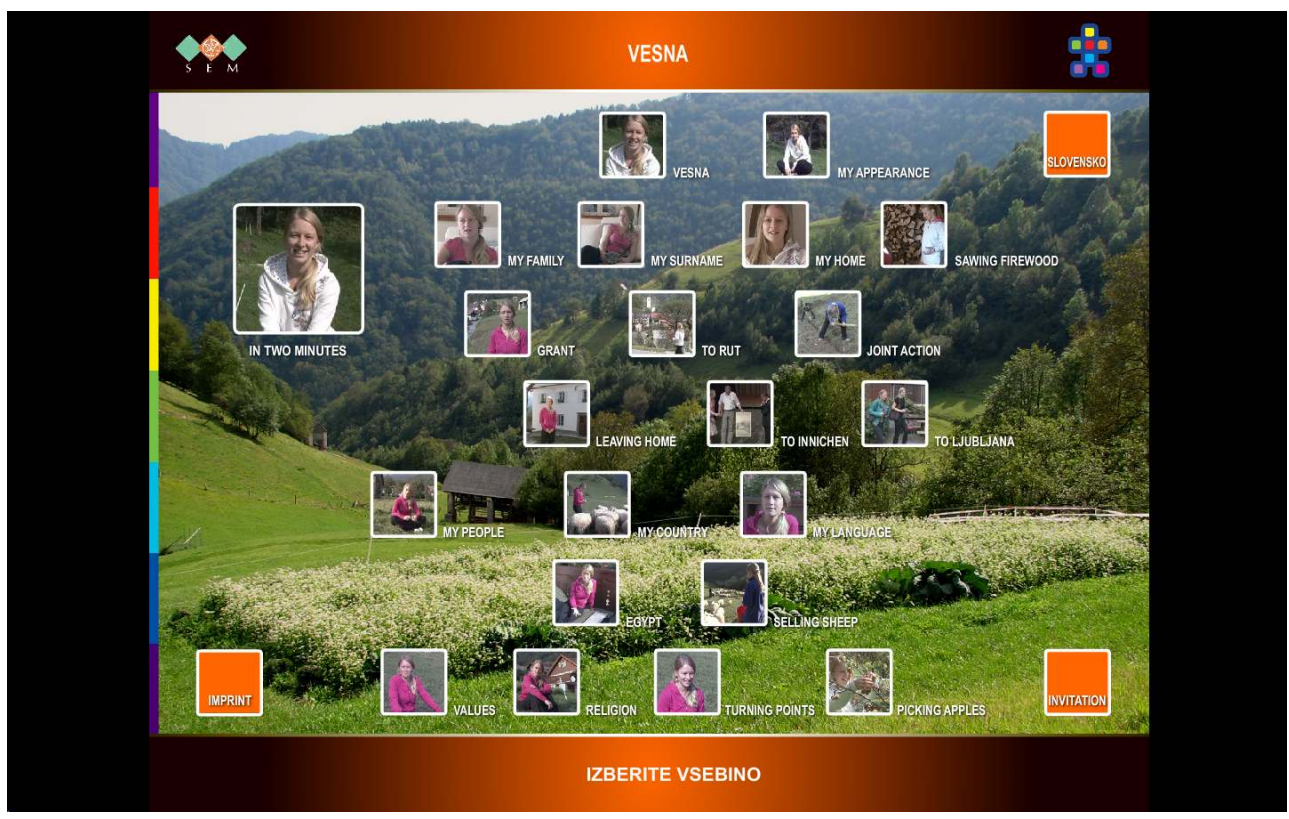

The introductory page of the mosaic portrait Vesna is an interface to 22 video clips, metadata and an invitation to send video contributions. SEM, 2009.

CREDIT = Idea Nadja Valentinčič Furlan, realisation Peter Gruden.

This media file cannot be displayed. Please refer to the online document http:// journals.openedition.org/anthrovision/3114

Video link: https://www.youtube.com/watch?v=XWk3nCv7zkl

In the living room of the exhibition I, We, and Others: Images of My World, visitors can switch from reception and inner reflection to sharing their views with others in collaborative approaches in various media.

\section{Participatory and Collaborative Approaches of the Open Part of the Exhibition}

Besides reflexivity, the strong values of this exhibition are participation and inclusion of vulnerable groups, through various forms of collaboration. In 2010, we organised a number of moderated group discussions on selected identity themes and workshops based on exchange of manual skills, however the greatest innovation is personal exhibitions by visitors. They are staged in two large rooms in the open part of the exhibition, being changed every few months. ${ }^{12}$ Their authors prepare them with the methodological, technical and media support of museum curators, while the content is their own and very subjective. Curators do our best to invite representatives of groups rarely presented in exhibitions, such as physically and sensory deprived people, Roma people, ${ }^{13}$ homeless people, refugees, minorities of all kinds, people with various sexual orientations, etc. Some visitors focus on their identities and ways of life, and some prefer to expose their private collections or their creativity in lace-making, painting, pottery, photographing and similar activities. As "participation is a contributive strategy in 
documenting the present" (Mensch and Meijer-van Mensch 2015: 58), exhibitions get a catalogue; hard copies are available in the living room and in the museum library, and a digital version is published online.

Based on the experience of visual anthropology with subject generated films and sharing authorship, we have also been developing reciprocal audiovisual communication with visitors, seeking their participation in filming portraits and narrations. They have been invited to take over the active role of film subjects or filmmakers. This is another way the museum facilitates visibility and giving voice to representatives of groups neglected in public media or treated in a stereotyped manner. Video portraits and narrations have the potential to enrich the exhibition with authentic Slovene and non-Slovene voices and images that provide an insight into how individuals experience themselves, their heritage, and their identities here and now.

This is also a long-term research project into the responsiveness of the museum audience, on how to approach potential collaborators, and what kind of assistance they need to accomplish their ideas. We realised that an invitation alone is not a sufficiently strong incentive for the visitors to film a portrait; they prefer to collaborate in filming their narrating, where the media and technical aspects are taken care of by the museum film crew. Since 2009, we have been cooperating with a pair of voluntary cultural mediators who enjoy filming the interviews and together we have been developing their sensitivity regarding how to approach the narrators and their subjectivity in an ethical manner. ${ }^{14}$

The "intellectual framework" (Postma 2003: 107) of filming is the narrator's identities the exhibition themes at the subjective individual level. The "social framework" (Postma 2003: 109-110) includes the narrator and the filmmakers, while the "visual framework" (Postma 2003: 111-112) is the narrator in the living room (the interviewer is not seen and her questions are edited out of the final product). The "temporal framework" (Postma 2003: 112-113) covers one to two hours for a tour around the exhibition given by Brigita Rupnik and one more for the filming. However, many narrators prepare for the interview very thoroughly, producing a comprehensive insight into their way of being and thinking. One elderly lady wrote down key moments of her professional career as a nurse on a piece of paper so that she would not forget to tell something that mattered to her. Filming this interview was like documenting her 'professional testament'. ${ }^{15}$ 
Figure 8: Narrators are filmed in the museum living room.

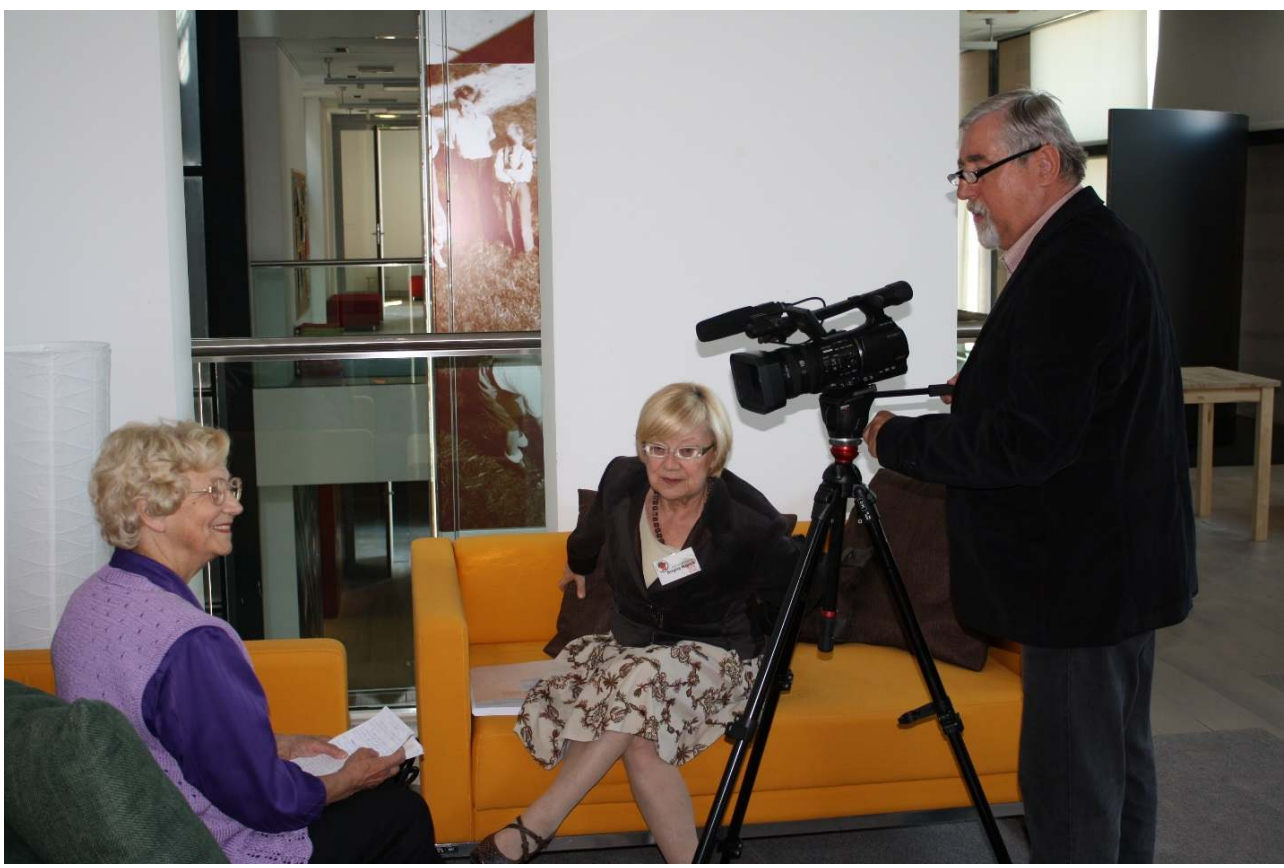

Olga Pivk is interviewed by Brigita Rupnik, and documented by Janez Doler, SEM, 2011.

Photo by Andreja Kofol.

This media file cannot be displayed. Please refer to the online document http:// journals.openedition.org/anthrovision/3114

Video link: https://www.youtube.com/watch?v=JdOFkNWoK9A

Cooperation between professionals and amateurs was labelled as the Pro-Am revolution by Charles Leadbeater and Paul Miller in 2004. If the $20^{\text {th }}$ century was shaped by the rise of professionals, the $21^{\text {st }}$ is time to bridge the professional-amateur divide. The enthusiasm of amateurs and professional standards of quasi (pre-, semi-, post-) professionals are now embodied in one person (Leadbeater and Miller 2004: 20-23). Initially, the cultural mediators at the Slovene Ethnographic Museum were amateurs with a great love of interviewing and filming; after nine years, they preserved the enthusiasm, having learned a lot.

Since 2010, we have filmed and edited 58 narrations and we also collected existing independent video portraits. The Gallery of Narrations and the Gallery of Portraits provide multiple perspectives and plural versions of the present and partly of the past, strengthening the social responsibility of the museum (cf. Black 2012: 215). New knowledge is constantly produced on video, and reflected back to the visitors in the open part of the exhibition.

\section{LGBT: An Exhibition of Four}

The permanent exhibition I, We, and Others: Images of My World presents an individual as a collection of socially constructed identities and roles. The term 'identity' connotes both a 
persistent sameness within oneself and sharing of some essential characteristics with others (Erikson 1980: 109). Thus, the formation of identities is a dynamic process embracing two contradictory concepts, similarity and distinction (Žagar 2019: 14). As the self-identification of individuals and groups is recognized retrospectively (Muršič 1997: 227), staging a personal exhibition or giving an interview for the Gallery of Narrations seems an excellent opportunity to review one's own identities and their development.

The LGBT exhibition was initiated by the museum, inviting Slovene lesbian, gay, bisexual and transsexual community to participate in preparing a personal exhibition. Writer and lesbian Suzana Tratnik, sociologist and gay person Roman Kuhar, Sinologist and bisexual person Jana S. Rošker, and media star and transsexual person Salomé responded to our invitation. All four presented themselves as active creators of their private and professional lives, with overt sexual identities and orientations, and also as activists. It was agreed that I would facilitate and coordinate this exhibition.

I felt my role as museum facilitator was to open discussion with questions such as: How will you conceive your own presentation? What objects, photos, texts, films and elements will you use? What is the message that you want to convey? Will you follow the same model or let each individual use a different model? How will you use space (separate stories or intertwined)? What is the time schedule of the exhibition? The title of the exhibition? What kind of events will you plan for the supporting programmes? I asked the authors how they saw the purpose of the exhibition and checked if they were ready to represent themselves as whole personalities, not exposing just sexual identities and orientations. Being aware from visual anthropology that multivocal and reflexive films are more likely to prompt spectators to activate their empathy and reflection, which can loosen the stereotypes (Ruby 1996: 196), I suggested creating a space of open dialogue, reflexivity and polyphony, with which they agreed. We took into account the mode of functioning, ethics, mission and identity of the museum, daring to see a bit beyond, too.

In October 2017, Suzana, Roman, Jana and Salomé produced an exhibition with 205 objects, many photographs and texts, revealing their personal views, existence and identities; the LGBT themes and activities were in focus, yet embedded in complex life stories. Four books were available on a table to be read and four narrations were shown in a loop on a screen. Alongside the LGBT: Exhibition of Four, the authors conceived five events that deepened the exhibition content. The first was a discussion on their identities and identification processes, and then each author proposed a thematic programme: three film evenings with discussion and a round table on latent public discourse regarding the non-existence of bisexuality. Before each event, one of the authors gave a tour around her/his part of the exhibition, and I briefly contextualised it as part of the permanent exhibition, so that the visitors got the overall picture; they were also invited to take an active part themselves. The project was developed with shared responsibilities of the four authors, their guests, me and the museum environment. 


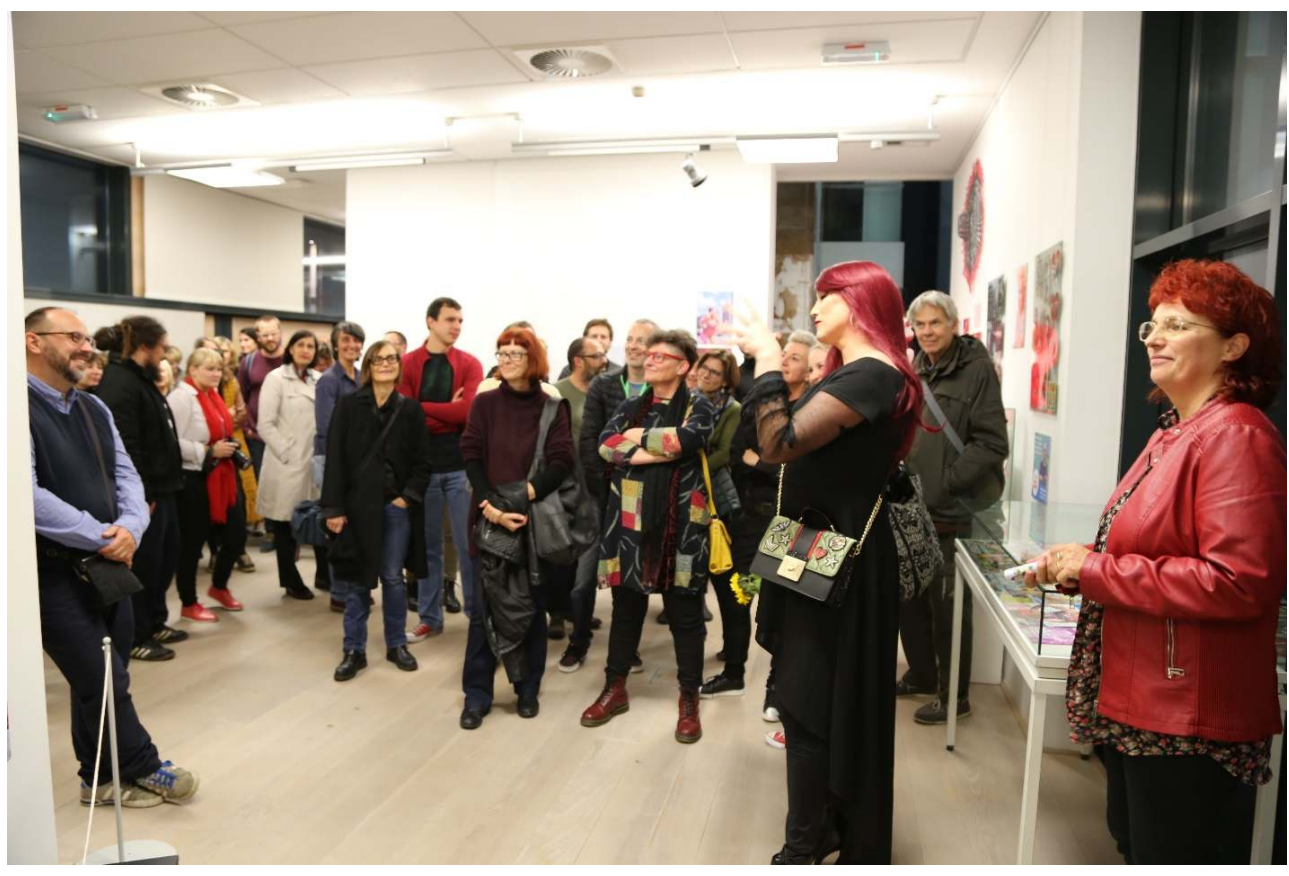

Opening of the personal exhibition LGBT: An Exhibition of Four, SEM, October 2017.

Photo by Jure Rus.

The authors and the museum could have chosen to represent the LGBT community in a different kind of exhibition, with a more historically oriented presentation of the phenomenon or from a radical, activist stance. However, we believe that with a softer, distinctively personal approach we avoided generalizations and stereotyping, thus increasing tolerance and respect. The museum offered a safe place to the authors as integral personalities with strong traits and vulnerability, and they made them available to public; visitors appreciated this stance.

I invited the authors to comment on their experience and their responses are published in the Catalogue LGBT: An Exhibition of Four. One of the four authors, Roman Kuhar, writes:

At the exhibition, I felt very 'naked', which is an interesting (and rather scary) experience. I have spoken about LGBT issues publicly many times, but the museum presentation opened up a few other dimensions, much more personal, intimate, and perhaps even painful. At the beginning, I thought that this would be one more 'activist task', which I would do just like any other. However, even selecting objects required much more time than I imagined, not to speak of the memories and feelings that such an act excites. The preparation of this exhibition was browsing my own history, and here, the exhibition caught me unprepared. However, I do not regret it. It was a great experience, which also shattered some stereotypes of museum life. (Filak ed. 2018: 107; my translation)

The exhibition and the events were attended by many insiders - members of LGBT community and their friends, but there were also outsiders, general public, curious people and groups of students. A young person commented: "This exhibition and film evenings have been of a great interest to me. This is how I imagine a modern museum" (Blaž, personal communication, my translation). ${ }^{16}$

47 A collaborative and co-creative exhibition (according to the scheme by Simon 2010: 190-191) meant that all participants have learned from each other. The authors have got 
to know the functioning of the museum, staging the exhibition and organising the programmes, and we have been learning about the specifics of their life and communication. Jana S. Rošker and her partner Téa told me that LGBT persons do not want to be labelled as Others (a concept from anthropology), and suggested the expression "a rainbow of human experience". For Roman Kuhar, the making of the exhibition appeared as yet another 'coming out'. We have learned that transsexual persons do not accept the sex attributed to them at birth, but choose it according to their own self-perception; they want to be addressed according to their preferences and many of them do not wish to undergo an operation at all. It was revealing to hear the writer Suzana Tratnik stating that the Slovene language was her homeland. And finally, I was amused and surprised more often than when collaborating in the organisation of traditional exhibitions and programmes.

I began to think about how we can contribute to change within the museum team (a fellow curator asked if we really needed such an exhibition) and outwards (on Facebook, an anonymous commentator wrote that the museum should not waste tax-payers' money on an exhibition like that). ${ }^{17}$ In April, we underwent a short seminar to obtain the 'LGBT Friendly' certificate awarded by the Municipality of Ljubljana. The emphasis was on how to create an inclusive environment for LGBT persons and to raise awareness of employees towards non-discriminatory services for all groups of visitors.

Preparing personal exhibitions seems particularly reasonable and worthy, if it brings about a transformative process in the museum and society (cf. Black 2012: 236), as well as on personal level. Jointly curated personal exhibitions are based on transparency and sharing authority (cf. Black 2012: 219-220). The inclusion of representatives of various social groups in museum work requires dialogical input by curators; it brings fresh ideas and energy, authenticity and honesty, and moreover, it opens new ethical issues, not hitherto considered.

Regarding audiovisual communication in the exhibition and in supporting programmes, I have discovered that the Slovenian LGBT community is very strong in media and filmmaking. Five quality films were included in the museum's programmes and I got permissions of filmmakers and film subjects that two would become part of the Gallery of Portraits. ${ }^{18}$ Thus, the traces of personal exhibitions continue to be visible in the living room after their closing and the network of museum exhibitions, programmes and projects is constructed.

This media file cannot be displayed. Please refer to the online document http:// journals.openedition.org/anthrovision/3114

Video link: https://www.youtube.com/watch?v=3IUTyO7G9_I

\section{Films and Exhibitions}

Generally speaking, exhibitions and films, both predominantly visual media, differ in the sense that exhibitions are principally spatial organisations of knowledge and films are temporal ones. Watching a film, we usually sit or stand and the pictures exchange in front of us, whereas observing an exhibition, we move around it. Thus, inserting films into an exhibition is a temporal principle embedded into a spatial one, so of course the films are not supposed to be too long. Moreover, an exhibition is largely a tangible medium and 
film is an intangible one, so they can complement each other very well. In my opinion, film is the best medium to present the knowledge and identities of people from their own point of view within the exhibition (when they cannot be present in person). ${ }^{19}$

Media points with films presenting the heritage and identities of film subjects can become powerful contact zones in the exhibition. However, the same media points become dead ends when equipment stops functioning and a black screen or white canvas is staring at the visitors. In permanent exhibitions, it may happen that not only the machines break down, but also new technological solutions are needed after some years. Refreshing the media content by replacing reproductive equipment with interactive technology on new interfaces can give new impetus to films, offering even more meaningful experience to the visitors.

I will elaborate on two cases from the Slovene Ethnographic Museum. In the first permanent exhibition, Between Nature and Culture (2006), we created a dialogue between a remarkable museum object, čupa (pronounced as chupa) Marija, the last completely preserved seagoing vessel made from a single hollowed trunk, and the film Čupa, the Vessel of Slovene Fishermen (2006). This filmic cultural biography presents the čupa Marija and its two careers: of marine dugout in Nabrežina (Aurisina), and of museum artefact in the Slovene Ethnographic Museum (more in Valentinčič Furlan 2015: 185-186). ${ }^{20}$ Since the original čupa Marija was transferred back to the depot to a stable climatic environment in 2015, and a model of the same proportions replaced her in the fishing room, the "aura" (according to Benjamin 1998: 151, 154) or uniqueness of the original object can no longer be felt. The film that helps visitors to connect to the exhibition theme thus gained even greater documentary value. ${ }^{21}$ For this reason, when modernising the reproductive technology in early 2017, we decided to install a much larger screen above it.

TITLE_ILLUSTRATION= Figure 10: A dialogue between object and its filmic biography.

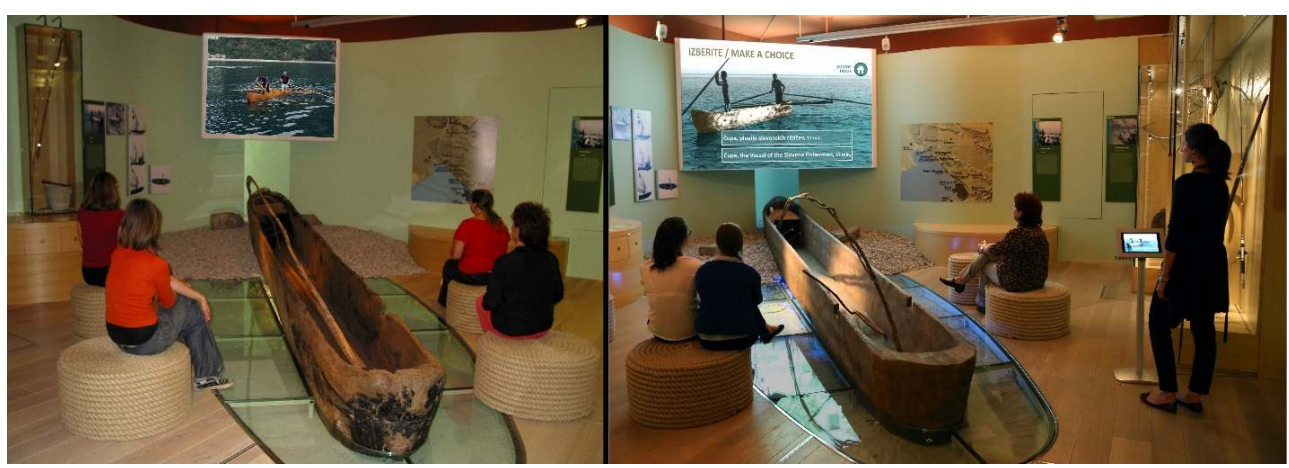

Left: The film projected on a screen above the čupa Marija reveals the exhibit's biography, while the authentic čupa supports the film with its presence, volume, appearance, material and smell; here, the museum object and the film were truly complementary modes. SEM, 2006. Right: The model has preserved the volume and the shape of the original, but the authenticity is lost. A larger screen has been installed above it and the interactivity is now enabled on a tablet on the right hand side. SEM, 2017

Photos by Nada Žgank and Jure Rus.

This media file cannot be displayed. Please refer to the online document http:// journals.openedition.org/anthrovision/3114

Video link: https://www.youtube.com/watch?v=SA9RIPSLw4g 

this gives them freedom for personalised viewing. ${ }^{22}$ The second permanent exhibition offers interactive access to home video, narrations and mosaic portrait, while The Gallery of Narrations and Portraits is available on a very old computer. When we launched the participatory audiovisual project in 2010, we could not know how collaboration with the visitors and cultural mediators would develop. In eight years, we have filmed 58 narrations and produced or collected 11 video portraits.

These 69 short contributions deserve to be better visible at the exhibition. In 2019, we plan to provide playback on demand on a large touch screen with a mosaic of faces and names. We feel great responsibility to the visitors and also to participants: narrators, cultural mediators, people portrayed, authors and producers of video portraits. ${ }^{23} \mathrm{We}$ are aware that a concluding media point with good reproduction and visibility will encourage visitors to further reflection, possibly attracting them to return to the museum as visitors and co-creators.

Figure 11: The concluding media point of the permanent exhibition.

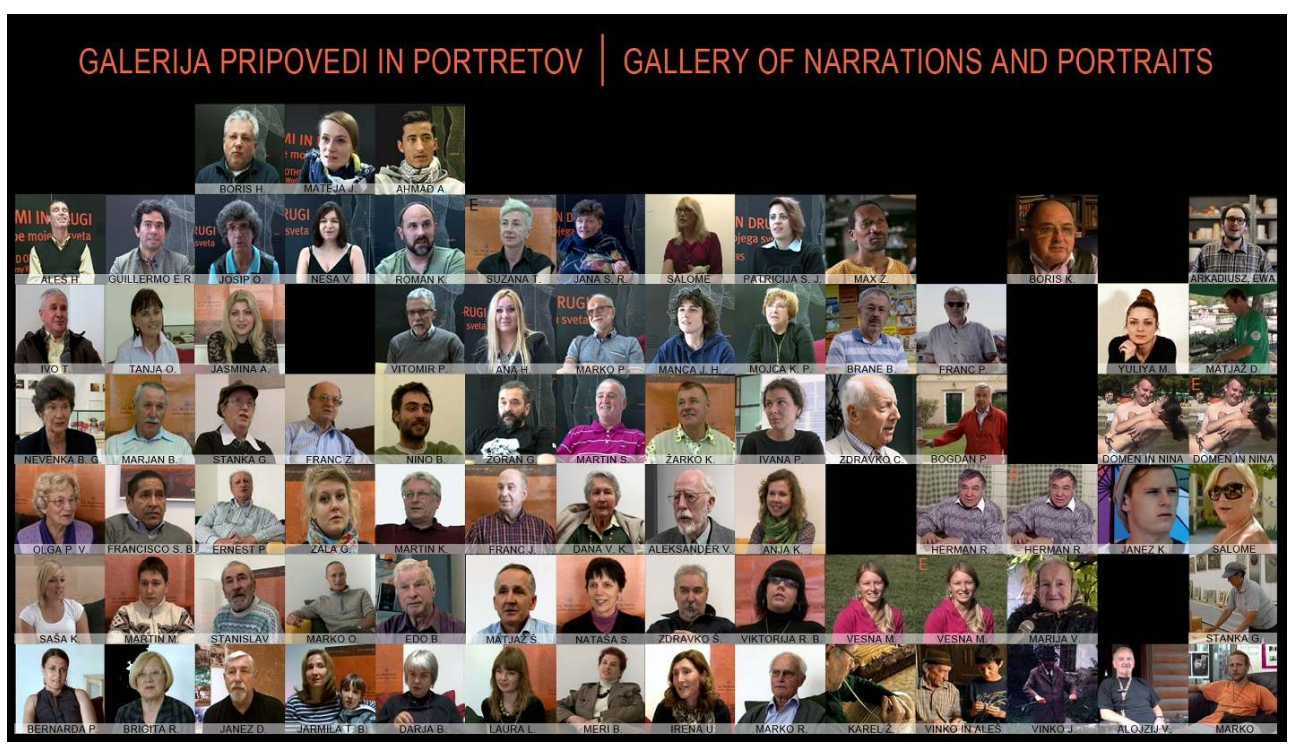

The introductory page of The Gallery of Narrations and Portraits on a touch screen. SEM, 2019.

Idea Nadja Valentinčič Furlan, realisation Joža Jamšek.

Meanwhile, the narrations are also available on the museum webpage in Digital Collections: Gallery of Narrators (Internet Source 3), next to Filmography of SEM (Internet Source 4). As a curator of ethnographic film I actively support the idea that museums are part of the media landscape by publishing video narrations, films and news on the webpage. I am fascinated that the number of visitors to the website and social networks exceeds the number of visitors to the museum by a factor of $15 .^{24}$

\section{Conclusions}

The exhibition I, We, and, Others: Images of My World discusses identity processes of individuals and groups, as well as the meanings and interpretations of personal, communal, national, human and museum heritage. The conceptual idea is based on 
cultural relativism as a way to understand the multicultural world (Lyotard 1979) and perceiving the reality as a social construct (Berger and Luckmann 1966), as stated by the author of the concept Janja Žagar (2010: 196-197). In postmodern world, meta-narratives are abandoned and substituted by fragmentation, fluidity and variability. The exhibition, itself also a construct, brings a variety of examples, a mosaic of identities, a network of personal stories, and moreover, knowing that the curators could never comprise all personal and group specifics, the visitors can add their own identities, heritages and views of life in the museum living room.

61 Visitors are not expected to be passive receivers of this exhibition, on the contrary, they are supposed to collect presented ideas actively - or maybe it is better to say 'select' in this multi-layered construction - and indulge in self-reflection (cf. reception theories of Appadurai and Breckenridge in their article with an inspiring title Museums Are Good to Think, 1992). And indeed, some feedbacks by visitors reveal how they experienced the exhibition: "A 'top important' issue exhibition that informs you about the past and gives you food for thought" (Aifidia). "I was fascinated by the exhibition showing how artificial and constructed all forms of culture are" (no name given). "I live between a Slovene village and Danish Copenhagen. When you take this road, you feel lost - you are neither Danish nor Slovene. The exhibition made me realised that I am not the only one, nor the first with this experience. If they have succeeded, I can, too" (Toni, my translation).

When scripting the exhibition, Janja Žagar wanted to address an individual as the smallest unit of humanity in the first place, therefore she expected the viewing would predominantly be an individual experience. On the contrary, the visitors very often preferred to join a guided tour, and many guides (curators and cultural mediators) elicited some feedback from them. Thus, the tour becomes an interactional and dialogic museum experience, where everybody is a specialist for their own identities and views, which are then simply added to the seen and heard. It is not rare that the same visitors later returned to deliberate a bit more on their own.

The exhibition accelerates the reflection of all parties engaged, as well as active participation of visitors revealing their subjectivity in personal exhibitions or filmic contributions. Both, staging personal exhibitions and taking part in filming the interviews, is realised with some methodological, media and technical support of museum curators and voluntary cultural mediators, therefore with shared responsibility. Curators encourage inclusion of groups rarely presented in museums and in public media by contacting their representatives and offering them visibility and support.

Through personal exhibitions and Gallery of Narrations, multivocality is enabled and multiple perspectives of subjective realities can be experienced in the museum. It is true that single-time-visitors see just one or two personal exhibitions, however, the catalogues are available in the museum living room and on the webpage also after the exhibitions are closed. Similarly, the narrations are accumulated at the exhibition and on the webpage. These soft, inclusive and multi-perspective strategies of knowledge construction and exhibiting clearly distance the Slovene Ethnographic Museum from "authorized heritage discourse" (Smith 2006: 4), at least in this exhibition and supporting programmes.

Let us return to Baxandall (1991: 2-3) and three agents in discerning the meaning in museum exhibitions: the creator of the object, the exhibitor who is the interpreter, and the viewer. In this exhibition, the main 'objects' are dynamic and fluid identities and 
views which are perceived as being co-created by subjects and embodied in them, yet at the same time also resulting from the socialisation and enculturation processes. Therefore, the same people, if open to inner reflection and ready to share their views, can here switch among different agent positions, as the exchange has no limits: visitors can become interpreters of their own identities and heritage, while curators are also viewers of personal exhibitions and filmic accounts by museum visitors. Thus, the construction of knowledge and identities is democratised here.

The last of the concepts applied, the Pro-Am approach, indicates the cooperation of professionals and amateurs (Leadbeater and Miller 2004). We practice it combining the enthusiasm of cultural mediators that give tours or film interviews under some guidance by curators; however, also personal exhibitions are prepared with cooperation of enthusiastic visitors and facilitating curators. The shaping of participatory personal exhibitions is oriented towards rich content, while the aesthetic value, due to financial limitations, mostly depends on in-house design. The concept of personal exhibitions has been applied in other occasional exhibitions of our museum and even 'exported' to other slovene museums.

Staging visitors' personal exhibitions in the museum and making their identities, knowledge and heritage available to other visitors, creates museum 'contact zones' (Clifford 1997). These are strengthened on openings, guided tours and interactive programmes, which generate contacts of individuals and groups that otherwise might not have met in the course of their lives. Filmed narrations and video portraits facilitate museum visitors to get to know film subjects and their life stories. Having established trustful, empathic and respectful contacts with film subjects, filmmakers share their understanding, captured in films, with the audience. It is becoming very common that museums host both, filmmakers and film subjects, in museum events or film festivals, where the audience can interact with them. To me, museum contact zones essentially mean that the engaged parties meet and learn from each other, so that new knowledge is generated via empathy, experience, reflection and analysis.

\section{BIBLIOGRAPHY}

\section{Books and articles}

Appadurai, Arjun, and Carol A. Breckenridge. 1992. Museums Are Good to Think: Heritage on View in India. In Museums and Communities: The Politics of Public Culture. Ivan Karp, Christine Mullen Kreamer and Steven D. Lavine, eds. Pp. 34-54. Washington and London: Smithsonian Institution Press.

Baxandall, Michael. 1991. Exhibiting Intention: Some Preconditions of the Visual Display of Culturally Purposeful Objects, https://butisitart.wikispaces.com/file/view/Baxandall+Exhibiting +Intention.pdf (accessed in June 2018); also published in Exhibiting Cultures: The Poetics and Politics of Museum Display. Ivan Karp and Steve D. Lavine, eds. Pp. 33-40. Washington: Smithsonian Institution Press. 
Benjamin, Walter. 1998. Umetnina v času, ko jo je mogoče tehnično reproducirati. Izbrani spisi. Pp. 145-176. Ljubljana: Studia Humanitatis.

Berger, Peter L., and Thomas Luckmann. 1966. The Social Construction of Reality: A Treatise in the Sociology of Knowledge. London et al.: Penguin Books.

Black, Graham. 2012. Transforming Museums in the Twenty-first Century. Abingdon and London: Routledge.

Clifford, James. 1997. Museums as Contact Zones. In Routes: Travel and Translation in the Late Twentieth Century. James Clifford, author. Pp. 188-219. Cambridge: Harvard University Press.

Clifford, James, and George E. Marcus, eds. 1986. Writing Culture: The Poetics and Politics of Ethnography. Berkeley, Los Angeles and London: University of California Press.

Dular, Jože. 1983. Krka pa teče naprej. Ljubljana: Mladinska knjiga.

Erikson, Erik H. 1980. Identity and Life Cycle: Selected Papers. New York: W. W. Norton.

Filak, Manca, ed. 2018. LGBT: Razstava štirih. Ljubljana: Slovenski etnografski muzej, https:// www.etno-muzej.si/files/exhibitions/katalog_lgbt_razstava_stirih.pdf (accessed in June 2018).

Frelih, Marko. 2007. Togo album: 1911-1914: Photographic Sources about the First Wireless Radiotelegraph Connection between Africa and Europe, Life in Togo and the Filming of The White Goddess of the Wangora. Ljubljana: Slovene Ethnographic Museum.

Ginsburg, Faye. 1995. The Parallax Effect: The Impact of Aboriginal Media on Ethnographic Film. Visual Anthropology Review 11(2): 64-76.

Hockings, Paul, ed. Principles of Visual Anthropology. De Hague and Paris: Mouton Publishers.

Hooper-Greenhill, Eilean. 2000. Museums and the Interpretation of Visual Culture. London and New York: Routledge.

Karp, Ivan. 1991. Culture and Representation. In Exhibiting Cultures: The Poetics and Politics of Museum Display. Ivan Karp and Steven D. Lavine, eds. Pp. 11-24. Washington: Smithsonian Institution Press.

Karp, Ivan, and Steven D. Lavine, eds. 1991. Exhibiting Cultures: The Poetics and Politics of Museum Display. Washington: Smithsonian Institution Press.

Kopytoff, Igor. 1986. The Cultural Biography of Things: Commoditization as Process. In The Social Life of Things: Commodities in Cultural Perspective. Arjun Appadurai, ed. Pp. 64-91. Cambridge: Cambridge University Press.

Leadbeater, Charles, and Paul Miller. 2004. The Pro-Am Revolution: How Enthusiasts are Changing Our Economy and Society. London: Demos.

Lévi-Strauss, Claude. 1966. The Savage Mind. London: Weidenfeld and Nicolson.

Lyotard, Jean-Francois. 1979. The Postmodern Condition: A Report on Knowledge. Theory and History of Literature Vol. 10. Manchester: Manchester University Press.

MacDougall, David. 1975. Beyond the Observational Cinema. In Principles of Visual Anthropology. Paul Hockings, ed. Pp. 109-124. De Hague and Paris: Mouton Publishers.

MacDougall, David. 1978. Ethnographic Film: Failure and Promise. Annual Review of Anthropology 7 (405-425). 
MacDougall, David. 1992. Whose Story Is It? In Ethnographic Film Aesthetics and Narrative Traditions: Proceedings from NAFA 2. Peter Ian Crawford and Jan Ketil Simonsen, eds. Pp. 25-42. Aarhus: Intervention Press and Nordic Anthropological Film Association.

Mensch, Peter van, and Leontine Meijer-van Mensch. 2015. New Trends in Museology. Celje: Museum of Recent History Celje.

Muršič, Rajko. 1997. »Razkritje krinke«: O lokalno-globalnih identifikacijah. Traditiones 26: 223-236.

Postma, Metje. 2003. Učna podlaga šole vizualnega v Novi Gorici. Glasnik SED 43 (1-2): 106-113.

Pratt, Mary Louise. 1992. Imperial Eyes: Travel Writing and Transculturation. London and New York: Routledge.

Rouch, Jean. 1975. The Camera and Man. In Principles of Visual Anthropology. Paul Hockings, ed. Pp. 83-102. De Hague and Paris: Mouton Publishers.

Ruby, Jay. 1996. The Viewer Viewed: The Reception of Ethnographic Films. In The Construction of the Viewer: Proceedings from NAFA 3. Peter Ian Crawford and Sigurjon Baldur Hafsteinsson, eds. Højbjerg: Intervention Press.

Ruby, Jay. 2000. Speaking For, Speaking About, Speaking With, or Speaking Alongside. In: Picturing Culture: Exploration of Film and Anthropology. Pp. 195-219. Chicago and London: The University of Chicago Press.

Simon, Nina. 2010. The Participatory Museum. Santa Cruz: Museum 2.0.

Smith, Laurajane. 2006. Uses of Heritage. London: Routledge.

UNESCO. 2003. Convention for the Safeguarding of the Intangible Cultural Heritage. Paris: UNESCO, https://ich.unesco.org/en/convention (accessed in June 2018).

Valentinčič Furlan, Nadja. 2006. Avdiovizualni kolaži na stalni razstavi Med naravo in kulturo. Etnolog 16 (243-262).

Valentinčič Furlan, Nadja. 2015. Visual Anthropology in Museums: The Case of the Slovene Ethnographic Museum. In: Vizualna antropologija: Osebne izkušnje in institucionalni vidiki / Visual Anthropology: Personal Experiences and Institutional Aspects. Miha Peče, Nadja Valentinčič Furlan and Monika Kropej Telban, eds. Pp. 177-204. Ljubljana: Založba ZRC.

Žagar, Janja. 2010. Kako nagovoriti in kaj spodbuditi: O stalni razstavi Jaz mi, in drugi. Podobe mojega sveta. Etnolog 20: 191-212.

Žagar, Janja. 2019. Between Starting Points and Structure, Message and Incentive. In I, We, and Others: Images of My World. A Guide to the Slovene Ethnographic Museum Permanent Exhibition. Janja Žagar ed. Pp. 9-29. Ljubljana: Slovene Ethnographic Museum.

Films

Dular, Andrej. 2008. Setting up a Maypole. SEM (production). 5 minutes.

Doler, Janez, Brigita Rupnik, Nadja Valentinčič Furlan. 2016. Suzana Tratnik. SEM (production). 8 minutes (an example from the Gallery of Narrations. 2010-2019. 290 minutes).

Matarranz, Eva, Anna Savchenko and Catarina Leal. 2014. God's Mistake / Božja napaka. Luksuz (production). 23 minutes.

Reichmann, Hanzi, Polona Sketelj and Nadja Valentinčič Furlan. 2008. Raubarjevi, interactive video application. SEM (production). 11 minutes. 
Schomburgk, Hans, dir. 1917. Im Deutschen Sudan (In German Sudan). Schomburgk Film (production, 76 minutes). Excerpts. 5 minutes.

Valentinčič Furlan, Nadja, and Polona Sketelj. 2006. Čupa, the Vessel of the Slovene Fishermen. SEM (production). 17 minutes.

Valentinčič Furlan, Nadja. 2008. My World through Fairy Tales and Life Experience, interactive application. SEM (production). 19 minutes.

Valentinčič Furlan, Nadja. 2009. Vesna, interactive video application. SEM (production). 33 minutes.

Valentinčič Furlan, Nadja. 2010. Vesna from Grant. SEM (production). 19 minutes.

\section{Exhibitions}

Between Culture and Nature, permanent exhibition. Concept by Andrej Dular, curators Igor Cvetko, Ralf Čeplak Mencin, Andrej Dular, Marko Frelih, Sonja Kogej Rus, Daša Koprivec, Bojana Rogelj Škafar, Anja Serec Hodžar, Polona Sketelj, Inja Smerdel, Nadja Valentinčič Furlan, Janja Žagar and Nena Židov. Ljubljana: SEM, 2006, https://www.etno-muzej.si/en/razstave/between-nature-andculture (accessed June 2018).

I, We, and, Others: Images of My World, permanent exhibition. Concept by Janja Žagar, curators Andrej Dular, Marko Frelih, Daša Koprivec, Polona Sketelj, Inja Smerdel, Nadja Valentinčič Furlan, Janja Žagar and Nena Židov. Ljubljana: SEM, 2009, https://www.etno-muzej.si/en/ razstave/i-we-and-others-images-of-my-world (accessed June 2018).

LGBT: Razstava štirih (LGBT: An Exhibition of Four), personal exhibition. Authors Suzana Tratnik, Roman Kuhar, Jana S. Rošker and Salomé, museum facilitator Nadja Valentinčič Furlan. Ljubljana: SEM, October 2017 - April 2018, https://www.etno-muzej.si/sl/razstave/lgbt-razstava-stirih (accessed June 2018).

\section{Internet sources}

Internet Source 1. The Coordinator for the Safeguarding of the Intangible Cultural Heritage, http://www.nesnovnadediscina.si/en/register-of-intangible-cultural-heritage (accessed April 2019).

Internet Source 2. SEM: Visitors' exhibitions, https://www.etno-muzej.si/sl/razstave/razstaveobiskovalcev (accessed June 2017).

Internet Source 3. SEM: Digital collections: Gallery of Narrators, https://www.etno-muzej.si/sl/ digitalne-zbirke/galerija-pripovedovalcev (accessed April 2019).

Internet Source 4. SEM: Digital collections: Filmography, https://www.etno-muzej.si/sl/ digitalne-zbirke/filmografija (accessed April 2019).

\section{NOTES}

1. Ruby's and MacDougall's articles were first published in Visual Anthropology Review 7(2) in 1991. They both have revealing titles: Speaking For, Speaking About, Speaking With, or Speaking Alongside An Anthropological and Documentary Dilemma (Ruby); Whose Story Is It? (MacDougall).

2. It should be stated that this evolution was enabled also by the development of recording devices from expensive, complicated and from the beginning silent film cameras to lighter and cheaper video cameras and, finally, to widespread digital recording technology; besides, various platforms make available easy distribution of digital contents. 
3. The SEM is largely a result of the so-called ethnology / anthropology at home, characteristic of Slavic ethnographic museums, yet it also partly integrates the Western concept of ethnographic museum. The domestic collections of the SEM are mostly the result of organised field research after World War 2, while non-European collections have come to the museum through missionaries, political representatives, researchers, innovators, sailors and travellers that originated in this area.

4. Video is also used to present a series of human faces in the introduction to the exhibition, and as a scenic element depicting fire in the hearth in the My family - my home section.

5. The traditional event was documented in 1994, and in 2008, the footage was edited into a 22 minute film and a 5 minute version for the exhibition context. Nowadays, this traditional custom could be enlisted as intangible cultural heritage, introduced by UNESCO in 2003. The SEM became the Coordinator for the Safeguarding of the ICH in Slovenia in 2011 (Internet Source 1).

6. This was selected to document the life context of headdresses made of cowrie shells that are part of the first permanent exhibition Between Nature and Culture.

7. All media created today to reconstruct the past is someone's audiovisual interpretation of the past. Filmmakers often use their imagination and artistic devices to fill in the missing visual parts of past jigsaw puzzles.

8. Krka pa teče naprej, Jože Dular, 1983. This novel is not a pure autobiography, although it is largely based on family history.

9. After the opening, the participants of personal exhibitions and narrations are usually first given a tour so that they understand the main points of departure.

10. The Primorsko region of Slovenia was annexed to Italy in 1921 by the Treaty of Rapallo.

11. Since the mosaic structure functions well only in the context of the exhibition, we also edited a linear film Vesna from Grant (2010). Vesna did not want it to be published online.

12. To date, 44 personal exhibitions have been realised (Internet Source 2).

13. These three categories were in focus in the project "Accessibility to Cultural Heritage by Vulnerable Groups", coordinated by the SEM in the years 2013-2016.

14. In 2009-2010, the Slovene Ethnographic Museum cooperated in the project "The Elderly as Bearers and Mediators of Intangible Cultural Heritage". Voluntary cultural mediators (retired people fond of heritage and museums) were first given an insight into the functioning of the museum and then they chose to become hosts at the exhibitions and programmes, or to give a hand in the museum library, documentation or restoration departments. They were thus engaged in the front-stage and back-stage operation of the museum. Ever since, four of them have continued their cooperation with the SEM, as is the case of the film crew.

15. The final video is 6 minutes long; however, the lady's grandchildren have transcribed the whole 60-minute interview, which was then partly published in a medicine journal.

16. A very insightful visitor's feedback on the role of personal exhibitions was written about the one prepared by an Argentinian migrant to Slovenia:

I do not know Gulliermo personally, but he is presented incredibly detailed in this exhibition. I congratulate the creators on capturing and linking all these exhibited valuables - he himself is the most important among them -, and also the Slovene Ethnographic Museum to provide home for things that could be lost in the vortex of oblivion (Lela, my translation).

17. Sexual identities and orientations are typical examples of the deconstruction of previously taken for granted facts. In the past, there was a clear division between men and women and straight sexual orientations were expected. In the postmodern world, these 'natural' division and expectations have been challenged in theory and practice; however, traditionalists do not accept new perceptions.

18. Collecting video portraits and making them visible at a media point inside the exhibition is close to hosting, one of the participatory approaches, dealt by Nina Simon (see Simon 2010: 190-191). 
19. After a tour given by Suzana Tratnik to LGBT: Exhibition of Four, she joined other visitors watching the narrations by her and other three authors. Watching and commenting on them together, revealed other aspects than the tour itself, giving additional value to the exhibition and the tour.

20. I take concepts "cultural biography of things" and "careers" from Igor Kopytoff (1986). The personality of čupa Marija and its social status among the fishermen deserved such representation.

21. Here we have a typical case of meaning construction among three agents (Baxandall 1991: 2-3): the creators and users of the object, museum and film interpreters, and the visitors. It came as a great surprise that in the 2017 evaluation, the visitors still found čupa the most memorable object in the Slovene Ethnographic Museum.

22. In the coming years we also need to modernise the reproduction of 19 Audiovisual Collages, with 72 short video clips in the first permanent exhibition. In the 2006 evaluation, we asked visitors if they would prefer interactive access to the collages via touch screens, and received equal positive and negative answers (Valentinčič Furlan 2006: 256-257). In the 2017 evaluation, even elderly people favoured interactivity; their grandchildren have taught them to use smart phones and there is no way back.

23. When I asked one of the filmmakers if she agreed to her self-portrait becoming part of the Gallery of Portraits, she was very proud, but when she saw it played back on the old computer, she did not hide her disappointment.

24. In 2018, 31,089 people visited the Slovene Ethnographic Museum, and 442,001 people contacted the museum webpage plus 19,972 the sub page of the Coordinator for the Safeguarding of the Intangible Cultural Heritage; additionally, 5,349 people followed Facebook, 1,783 Twitter and 1,020 Instagram.

\section{ABSTRACTS}

The author, a curator of ethnographic film at the Slovene Ethnographic Museum, and a producer of several films and curated elements at the museum, presents numerous collaborative and participatory approaches applied at her museum. She focuses on the use of film in interactive media points in exhibitions and the production of new audiovisual accounts in cooperation with visitors and cultural mediators. She analyses the overall exhibition narrative in the permanent exhibition I, We, and Others: Images of My World, various filmic interventions and co-curated personal exhibitions by museum visitors. She proposes to understand personal exhibitions and subjective filmic contributions as 'contact zones' for various individuals and groups at the Slovene Ethnographic Museum.

L'auteure, conservatrice de films ethnographiques au Musée ethnographique slovène et productrice de plusieurs films et d'élements conservées au musée, présente de nombreuses approches de collaboration et de participation au sein de son musée. Elle se concentre sur l'utilisation du film dans les médias interactifs dans le cadre des expositions et sur la production de nouveaux récits audiovisuels en coopération avec les visiteurs et les médiateurs culturels. Elle analyse l'ensemble des récits constitués autour de l'exposition permanente $\mathrm{I}$, We, and Others : Images de mon univers, les diverses interventions filmiques et les expositions personnelles coprésentées par des visiteurs du musée. Elle propose de percevoir les expositions personnelles et 
les contributions filmiques subjectives comme des " zones de contact " possibles quel que soit le public visé et visitant le musée ethnographique de Slovénie.

La autora, conservadora de películas etnográficas en el Museo Etnográfico de Eslovenia y productora de varias películas así como conservadora de elementos en el museo, presenta numerosas perspectivas de colaboración y participación aplicadas en su museo. Se centra en el uso de películas en espacios con medios interactivos en exposiciones y en la producción de nuevos registros audiovisuales en cooperación con visitantes y mediadores culturales. Analiza la narrativa general de la exposición permanente I, We, and Others: images of My World, diversas intervenciones fílmicas y exposiciones personales co-curadas por los visitantes del museo. Propone entender las exposiciones personales y las contribuciones cinematográficas subjetivas como "zonas de contacto" para varias personas y grupos en el Museo Etnográfico de Eslovenia.

\section{INDEX}

Mots-clés: connaissances, identités, film, exposition, musée, communication, participation, inclusion, co-création, paradigme Pro-Am, communauté LGBT, zone de contact

Palabras claves: conocimiento, identidades, cine, exposición, museo, comunicación, participación, inclusión, co-creación, paradigma Pro-Am, comunidad LGBT, zona de contacto Keywords: knowledge, identities, film, exhibition, museum, communication, participation, inclusion, co-creation, Pro-Am paradigm, LGBT community, contact zone

\section{AUTHOR}

\section{NADJA VALENTINČIČ FURLAN}

Curator of ethnographic film, Slovene Ethnographic Museum

Nadja.Valentincic@etno-muzej.si

Nadja Valentinčič Furlan is a museum counsellor at the Slovene Ethnographic Museum in Ljubljana, Slovenia, heading the Department of Ethnographic Film. She designs audiovisual communication inside exhibitions, interprets film heritage and produces ethnographic films, recently with focus on intangible cultural heritage. She publishes on the use of films in museum exhibitions, visual anthropology, intangible cultural heritage, life stories, memories and research ethics. She is a member of VANEASA network committee and part of the AnthroVision editorial board. She has edited two volumes on visualization of the intangible cultural heritage. Her current research is focused on participation of heritage bearers in film productions on intangible cultural heritage for the UNESCO lists. 